\title{
INFLUENCE OF D-GLUCOSE ON CORROSION RESISTANCE OF SS316 LIN PRESENCE OF ARTIFICIAL SALIVA
}

\author{
R. Saranya ${ }^{1, *}$ and Susai Rajendran ${ }^{2}$ \\ ${ }^{1}$ Research and Development Centre, Bharathiyar University, \\ Coimbatore-641046, Tamil Nadu, India \\ ${ }^{1}$ Department of Chemistry, Jayalakshmi Institute of Technology, \\ Thoppur-636352, Tamil Nadu, India \\ ${ }^{2}$ Corrosion Research Centre, Department of Chemistry, \\ St Antony's College of Arts and Sciences for Women, Dindigul-624005, Tamil Nadu, India \\ *E-mail: senthilkumar944@gmail.com
}

\begin{abstract}
In the oral environment, orthodontic appliances are exposed to potentially damaging Physical and chemical agents which may cause metallic corrosion. The study reveals that there is a strong dependence of the corrosion resistance of SS316L on the concentration of D-Glucose in the electrolyte medium. The corrosion behavior of experimental Stainless steel 316L alloy has been carried under artificial saliva (AS) condition in presence of D-Glucose. Corrosion resistance and ability to form protective oxide scales are evaluated and compared with polarization study and AC impedance spectra. The SS316L orthodontic alloy so better corrosion resistance in all experimental condition than other alloys. This agrees with the results obtained potentiodynamic polarization curves and AC impedance spectra.
\end{abstract}

Keywords: Corrosion of metal, artificial saliva (AS), SS316L, D-Glucose.

(c) RASĀYAN. All rights reserved

\section{INTRODUCTION}

Biomedical materials play a vital role in the manufacturing of Prosthetic devices in the modern world. Prosthetic devices are artificial replacements, which are used, in biological system. ${ }^{1}$ These devices are generally made up of polymeric, metallic and ceramic material. The important requirement for any material to place in the human body is biocompatible and not to cause any adverse reaction in the body. Corrosion resistance is an important property for dental materials. Oral environment is one of the factors responsible for the formation of corrosion products. The mouth is moist and continually subjected to fluctuations in temperature. Foods and drinks cause transitory, but important and wide, variations in the chemistry of the environment. The most important fluid in the oral environment is represented as natural saliva. It is obvious about tests involving dental material should be done in that media., ${ }^{2}$ However, the unstable nature of natural saliva makes it inadequate for standardized in-vitrostudies and artificial saliva is frequently used. The artificial saliva generally used in corrosion studies of dental alloys.

In dentistry, metallic materials there are implants in reconstructive of oral surgery to replace single teeth or an array of teeth or in the fabrication of dental prostheses such as metal plates for complete and partial dentures, crowns and bridges, essentially in patients requiring hypoallergenic materials. ${ }^{4}$ Corrosion of metallic implants will play vital importance because it can adversely affect the biocompatibility and mechanical integrity of implants. Many metals and alloys have been used in dentistry field that alloy has been considered the problem for long durability of implants into the human bodies verse and release of metal ions will cause adverse physiological effects, toxicity on exposure to air to form an oxide layer spontaneously on the surface of biomedical alloys. ${ }^{5,6}$ The corrosion resistance of these alloys is owed to the presence of this thin passive oxide film on its surface. The physicochemical properties of the passive film control the corrosion behavior of materials and the interaction with tissues, surrounding of the body. ${ }^{7-10}$ Over the past two decades, with the accelerated development of tissue engineering, the demands 
RASĀYAN J. Chem.

Vol. 11 | No. 1 |103-110 | January - March | 2018

for a variety of synthetic and natural biomaterials have been dramatically increased. A biomaterial sale has already exceeded $\$ 240$ million per year and due to the rapid development of biomaterials. The market will increase their product for tissue engineering and artificial organ materials. Specifically, cost related point of view an organ replacement accounts for $8 \%$ of global healthcare. Such demands require unique, better performing biomaterials for regenerative medicine. For example, it is necessary to develop better material for mechanical properties and biocompatibility. Conventional biomaterials (or those materials with constituent dimensions greater than $1 \mu \mathrm{m}$ ) have not satisfactorily met clinical demands. Hence, Researchers, clinicians, and other investigators are seeking for better novel materials to serve for the next generation of tissue engineering and artificial organ materials.

\section{Artificial saliva}

\section{EXPERIMENTAL}

The intention of being as close as possible to clinical conditions, artificial saliva was chosen as the electrolyte, Open to the atmosphere at $37^{\circ} \mathrm{c}$. The test solution used was the artificial saliva from Fusayama and Meyer B. Its Composition is shown in table-1. The test solution had to be used shortly after preparation because of urea's instability.

Table -1: Composition of artificial saliva ${ }^{11-13}$

\begin{tabular}{c|c}
\hline & Quantity $\mathrm{gL}^{-1}$ \\
\hline $\mathrm{KCl}$ & 0.4 \\
\hline $\mathrm{NaCl}$ & 0.4 \\
\hline $\mathrm{CaCl}_{2} .2 \mathrm{H}_{2} \mathrm{O}$ & 0.906 \\
\hline $\mathrm{NaH}_{2} \mathrm{PO}_{4} 2 \mathrm{H}_{2} \mathrm{O}$ & 0.690 \\
\hline $\mathrm{Na}_{2} \mathrm{~S}_{9} 9 \mathrm{H}_{2} \mathrm{O}$ & 0.005 \\
\hline Urea & 1 \\
\hline
\end{tabular}

\section{Orthodontic Wires}

The orthodontic wire316L stainless steel was chosen for the present study. The composition of wire is given in Table-2.

Table -2: Composition of SS316L ${ }^{14,15}$

\begin{tabular}{c|c}
\hline Composition & Percentage [\%] \\
\hline Chromium & 18 \\
\hline Nickel & 12 \\
\hline Molybdenum & 2.5 \\
\hline Carbon & $<0.03$ \\
\hline Iron & Balance \\
\hline
\end{tabular}

\section{Oral fluids}

Glucose is the human body's key source of energy. It supplies almost all the energy for the brain. Therefore, its availability influences psychological process when glucose is low, psychological process requiring mental effort. D-Glucose was taken as oral fluids for this study.

\section{Polarization study}

Polarization methods were often used for laboratory corrosion testing. These techniques can provide useful information regarding the corrosion mechanisms and susceptibility of specific materials. Polarization studies were investigated in a CHI Electrochemical workstation/analyzer, model 660A.It was provided with automatic IR compensation facility. The SS316L alloy as working electrodes the other two electrodes were saturated calomel electrode (SCE) as a reference electrode and platinum foil as the counter electrode. A time interval of 5 to 10 minutes was given for the system to attain a steady state of open circuit potential. The working electrode and platinum electrode were immersed in artificial saliva in the absence and presence of D-Glucose. From the polarization study corrosion parameters such as corrosion potential $\left(\mathrm{E}_{\mathrm{corr}}\right)$, corrosion current $\left(\mathrm{I}_{\mathrm{corr}}\right)$, Tafel slopes $\left(\mathrm{b}_{\mathrm{a}}\right.$ and $\mathrm{b}_{\mathrm{c}}$ ) and linear polarization 
RASĀYAN J. Chem.

Vol. 11 | No. 1 |103-110 | January - March | 2018

resistance (LPR) were calculated. During the polarization study, the scan rate (V/s) was 0.01 Hold time at $\mathrm{E}_{\mathrm{f}}(\mathrm{s})$ was zero and quiet time $(\mathrm{S})$ was two.

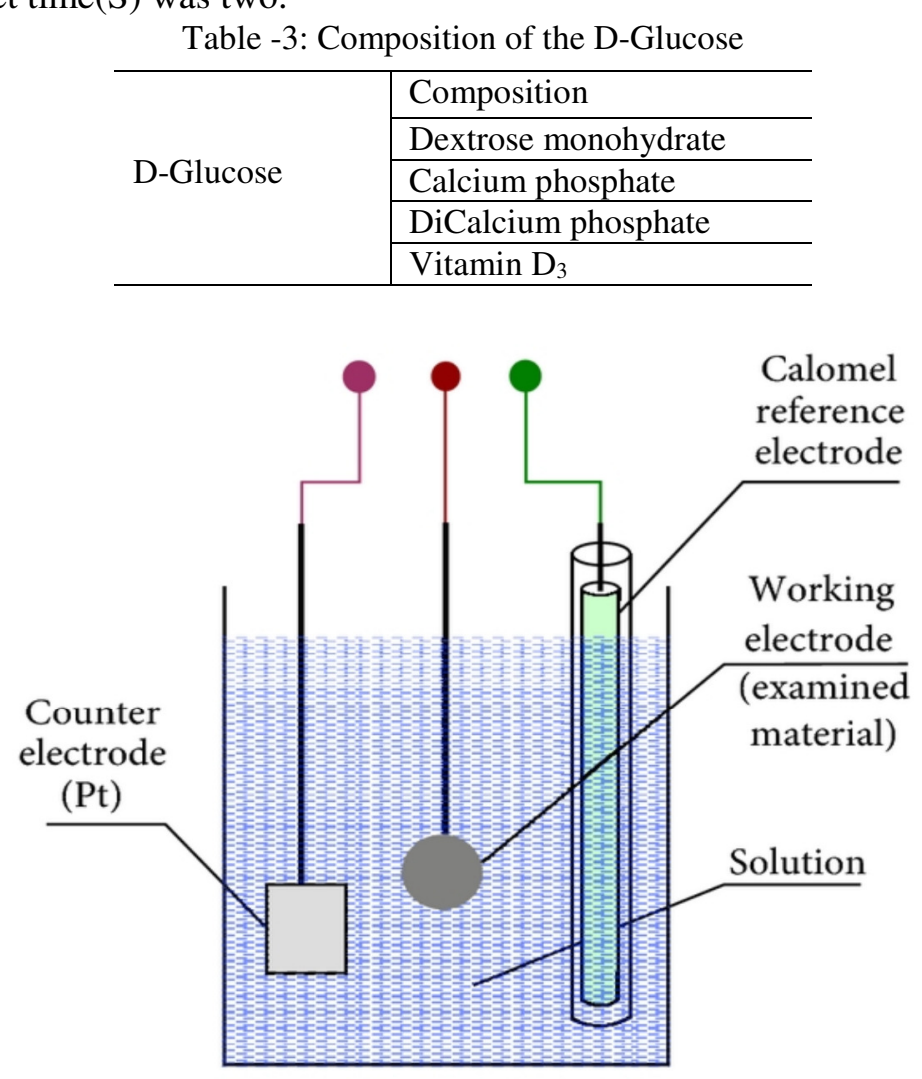

Fig.- 1: Schematic diagram of three-electrode cell assembly

\section{AC Impedance Spectra}

An AC impedance spectrum [electrochemical impedance spectra] has been used to confirm the formation of a protective film on the metal surface. The instrument used for polarization study was used to record AC impedance study also the same. A CHI electrochemical impedance analyzer (model 660A) was used for AC impedance measurements. A time interval of 5 to 10 minutes was given for the system to attain its open-circuit potential. The real part (z') and imaginary part (z') of the cell impedance were measured in ohms at various frequencies (f). The values of the charge transfer resistance $R_{t}$ and the double layer capacitance $C_{\mathrm{dl}}$ were calculated from Nyquist plots. Impedance $\log (\mathrm{z} / \mathrm{ohm})$ value was calculated from Bode plots.

Table-4: Corrosion parameters of metals immersed in AS in the absence and presence of D-Glucose obtained by polarization study

\begin{tabular}{c|c|c|c|c|c|c}
\hline \multirow{2}{*}{ Metal } & System & $\begin{array}{c}\mathrm{E}_{\text {corr }} \\
\mathrm{mVvSSCE}\end{array}$ & $\begin{array}{c}\mathrm{I}_{\text {corr }} \\
\mathrm{A} \mathrm{cm}^{-2}\end{array}$ & $\begin{array}{c}\mathrm{b}_{\mathrm{a}} \\
\mathrm{mVdecade}^{-1}\end{array}$ & $\begin{array}{c}\mathrm{b}_{\mathrm{c}} \\
\mathrm{mVdecade}^{-1}\end{array}$ & $\begin{array}{c}\text { LPR } \\
\text { Ohmcm }^{2}\end{array}$ \\
\hline \multirow{3}{*}{$\mathrm{SS} 316 \mathrm{~L}$} & $\mathrm{AS}$ & 279 & $7.224 \times 10^{-7}$ & 312 & 260 & 324807 \\
\cline { 2 - 7 } & AS+150D-Glucose & 258 & $4.658 \times 10^{-7}$ & 189 & 210 & 664123 \\
\cline { 2 - 7 } & AS+300D-Glucose & 243 & $3.752 \times 10^{-7}$ & 236 & 172 & 698732 \\
\hline
\end{tabular}

\section{RESULTS AND DISCUSSION}

Polarization study has been used to investigate the formation of the protective film, which formed on the metal surface during corrosion process. If corrosion resistance increases, the linear polarization resistance (LPR) value increases and corrosion current decreases. ${ }^{16-24}$ The present experiment has proved that while increases the LPR value the lower corrosion current. From the Table- 4 there is also electrochemical 
parameters, mentioned for the three metals dissolution in artificial saliva. These parameters are such as corrosion potential $\left(\mathrm{E}_{\mathrm{corr}}\right)$, corrosion current $\left(\mathrm{I}_{\mathrm{corr}}\right)$, Tafel slopes $\left(\mathrm{b}_{\mathrm{a}}\right.$ and $\left.\mathrm{b}_{\mathrm{c}}\right)$ and linear polarization resistance (LPR).

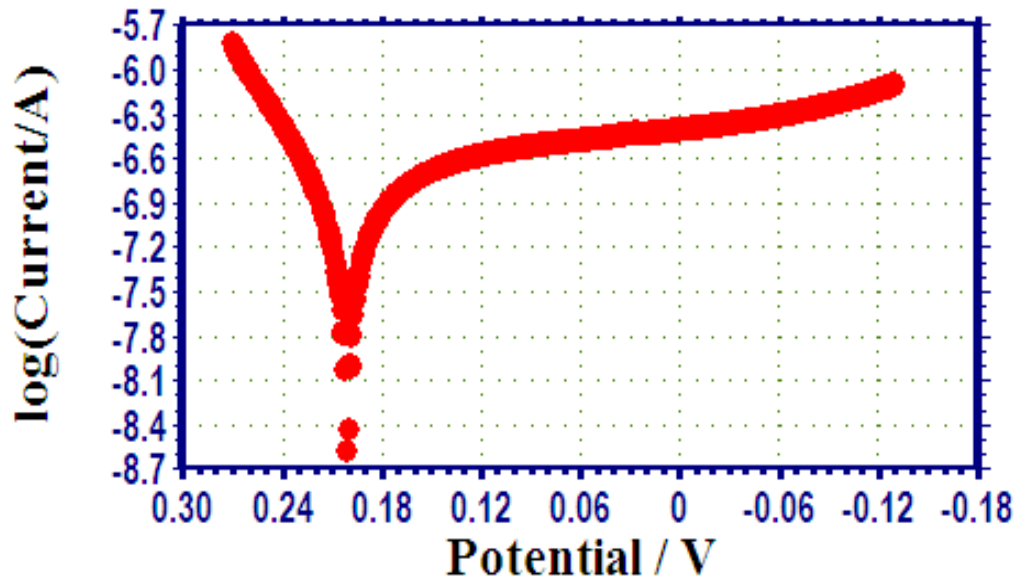

Fig.- 2: Polarization curves of SS316L immersed in AS

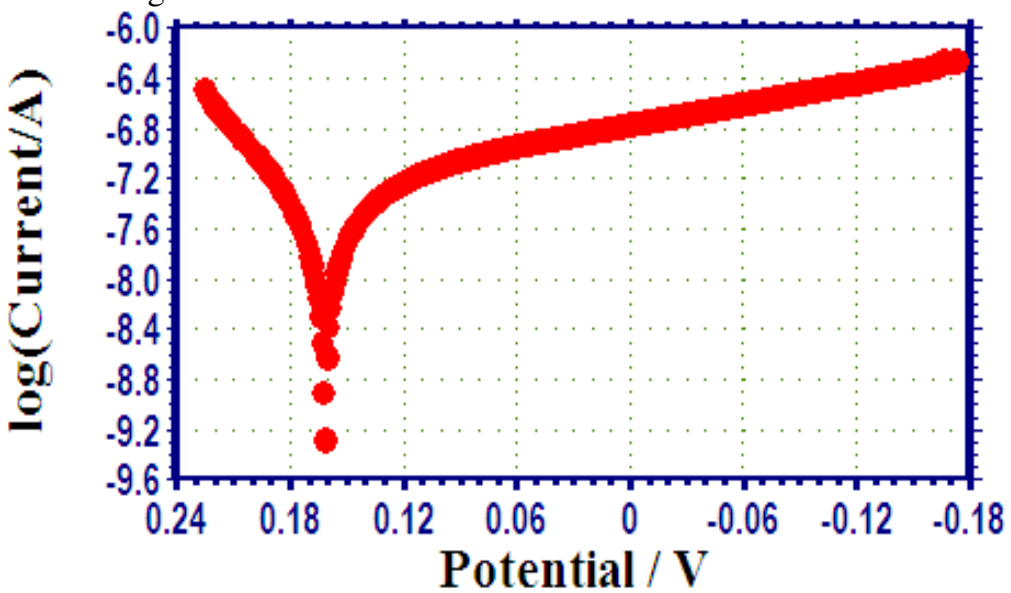

Fig.-3: Polarization curves of SS316L immersed in AS +150ppm D-Glucose

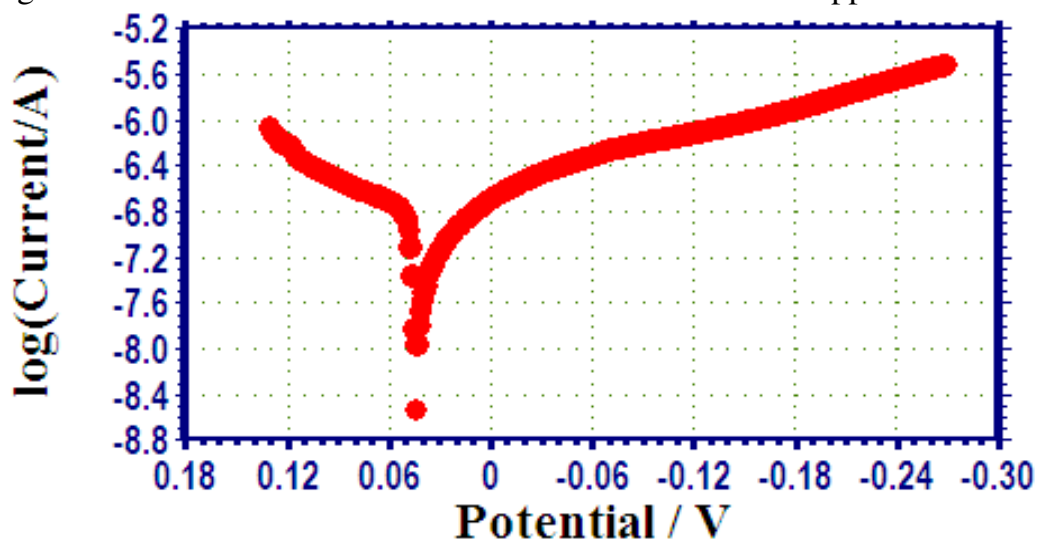

Fig.- 4: Polarization curves of SS316L immersed in AS +300ppm D-Glucose

Analysis of Potentiodynamic Polarization Curves

When SS316L is immersed in AS containing D-Glucose the corrosion potential is $279 \mathrm{mV}$ vs SCE. The increasing concentration (150ppm) the potential is shifted to cathodic side (279 to $258 \mathrm{mV}$ vs SCE). The LPR value increases from 324807 to $664123-\mathrm{ohm} \mathrm{cm} \mathrm{cm}^{2}$, corrosion current decreases from $7.224 \times 10^{-7}$ to $4.658 \times 10^{-7} \mathrm{~A} / \mathrm{cm}^{2}$. The addition of 300ppm of D-Glucose LPR value increases from 664123to 698732- 
RASĀYAN J. Chem.

Vol. 11 | No. 1 |103-110 | January - March | 2018

$\mathrm{ohm} \mathrm{cm}^{2}$ and corrosion current decreases from $4.658 \times 10^{-7}$ to $3.752 \times 10^{-7} \mathrm{~A} / \mathrm{cm}^{2}$.It is well known that LPR value is better to increase due to the formation of a protective film on the metal surface. From the results of the experiment performed on the orthodontic alloy, it appears clear that the differences in concentration create a difference in electrochemical behavior. This was shown by in the polarization curves.

The difference in corrosion behavior of metals and alloys is due to the spontaneous formation of a thin, compact layer of oxides called the passive layer. The corrosion resistance and stability of their passive oxide films are quite different. Corrosion of dental alloy is complex process depends not only on alloy's composition and on structure, but also on many other factors such as surface conditions, treatment, certain environmental conditions around the alloy and composition of the surrounding electrolyte. Results from potentiodynamic tests revealed that stainless steel has the best resistance to corrosion.

Table-5: Corrosion parameters of metals immersed in AS in the absence and presence of D-Glucose obtained by AC impedance spectra

\begin{tabular}{c|c|c|c|c}
\hline Metal & System & $\mathrm{R}_{\mathrm{t}} \mathrm{ohm} \mathrm{\textrm {cm } ^ { 2 }}$ & $\mathrm{C}_{\mathrm{dl}} \mathrm{F} \mathrm{Cm}^{2}$ & $\begin{array}{c}\text { Impedance } \\
\mathrm{Log}(\mathrm{Z} / \mathrm{ohm})\end{array}$ \\
\hline \multirow{3}{*}{ SS316L } & AS & 491375 & $3.6354 \times 10^{-9}$ & 4.32 \\
\cline { 2 - 5 } & AS+150D-Glucose & 641109 & $2.1481 \times 10^{-9}$ & 4.36 \\
\cline { 2 - 5 } & AS+300D-Glucose & 821874 & $1.8359 \times 10^{-9}$ & 4.45 \\
\hline
\end{tabular}

\section{Analysis of the Results of AC Impedance Spectra}

The AC impedance parameters namely charge transfer resistance $\left(R_{t}\right)$ and the double layer capacitance $\left(\mathrm{C}_{\mathrm{dl}}\right)$ are given in Table-5. When corrosion rate decreases, due to the formation of the protective film, the charge transfer resistance value increases and double layer capacitance value decreases; the impedance value $\log (\mathrm{Z} / \mathrm{ohm})$ increases. This behavior means that the film obtained acts as a barrier to the corrosion process that clearly proves the formation of the film. ${ }^{25-30}$ When SS316L is immersed in AS containing DGlucose the blank system $R_{t}$ value is $491375 \mathrm{ohm} \mathrm{cm}^{2}$ and $C_{\mathrm{dl}}$ value is $3.6354 \times 10^{-9} \mathrm{~F} / \mathrm{cm}^{2}$. The concentration of $150 \mathrm{ppm}$ of D-Glucose the $\mathrm{R}_{\mathrm{t}}$ value is increasedfrom 491375 to641109 $\mathrm{ohmcm}^{2}$ and the $\mathrm{C}_{\mathrm{dl}}$ value decreased from $3.6354 \times 10^{-9}$ to $2.1481 \times 10^{-9} \mathrm{~F} / \mathrm{cm}^{2}$. When compared to the blank value the $150 \mathrm{ppm}$ of $\mathrm{R}_{\mathrm{t}}$ and $\mathrm{C}_{\mathrm{dl}}$ values are high. The addition of $\mathrm{D}$-Glucose to $300 \mathrm{ppm} \mathrm{R}_{\mathrm{t}}$ value increases from 641109 to $821874 \mathrm{ohmcm}^{2}$ and the $\mathrm{C}_{\mathrm{dl}}$ value decreases from $2.1481 \times 10^{-9}$ to $1.8359 \times 10^{-9} \mathrm{~F} / \mathrm{cm}^{2}$. These observations indicate that the corrosion resistance of SS316L in the presence of D-Glucose due to the formation of a protective film on the metal surface. SS316L was more stable and prevented the loss of an electron from the metal.

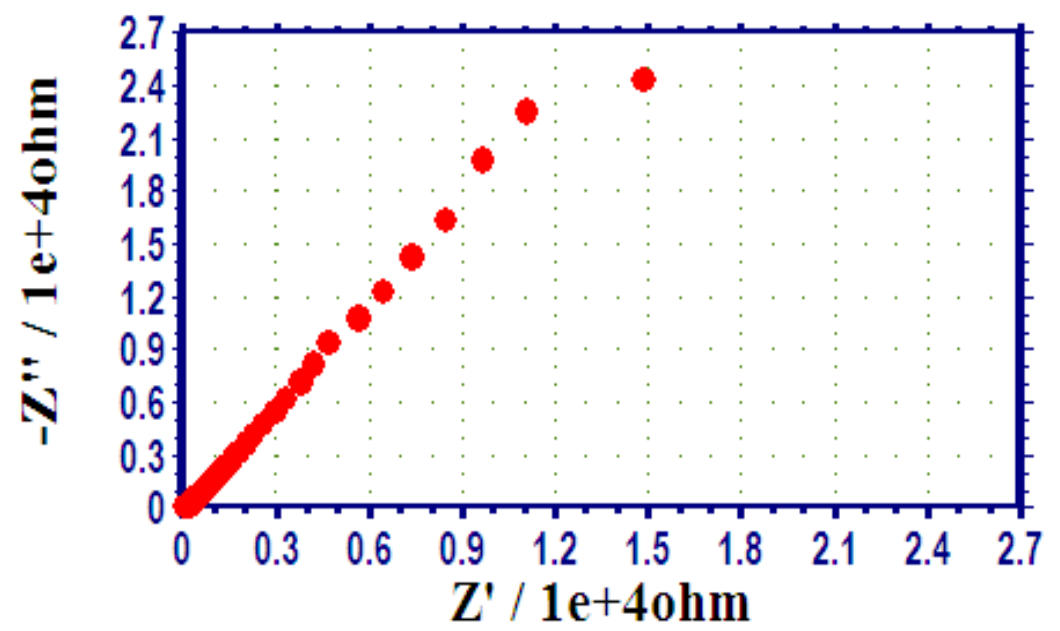

Fig.-5: AC impedance spectra (Nyquist plots) of SS316L immersed in AS 
The presence of the film, the film formation signifies the charge transfer resistance increased and the double layer capacitance value decreased, because they were inversely related to each other. SS316L was able to withstand the attack of aggressive ions present in AS. Therefore, SS316L was more corrosion resistant.

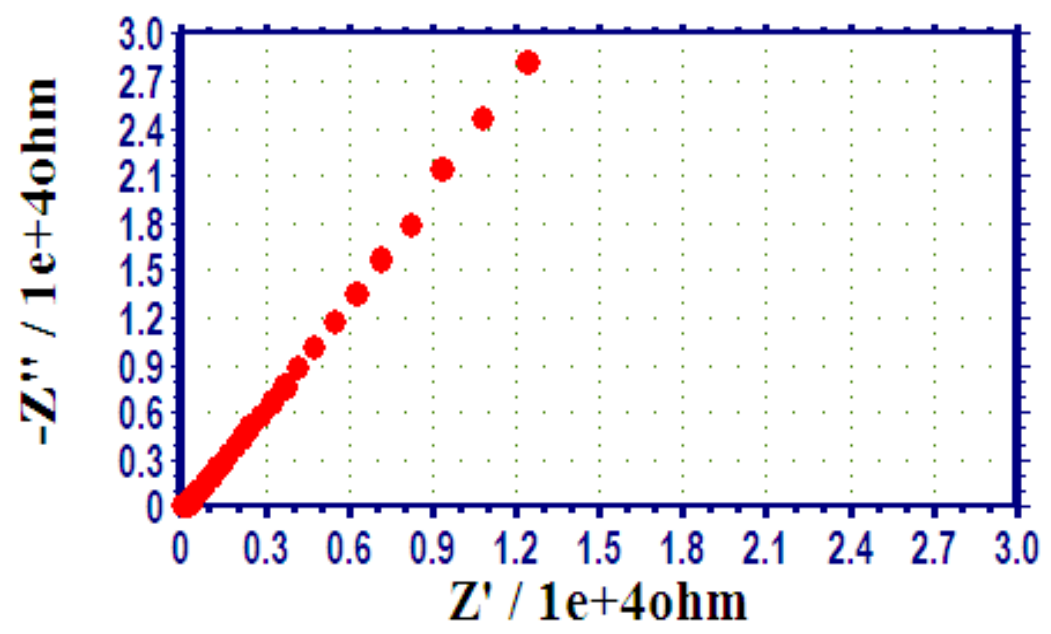

Fig.-6:AC impedance spectra (Nyquist plots) of SS316L immersed in AS +150ppm D-Glucose

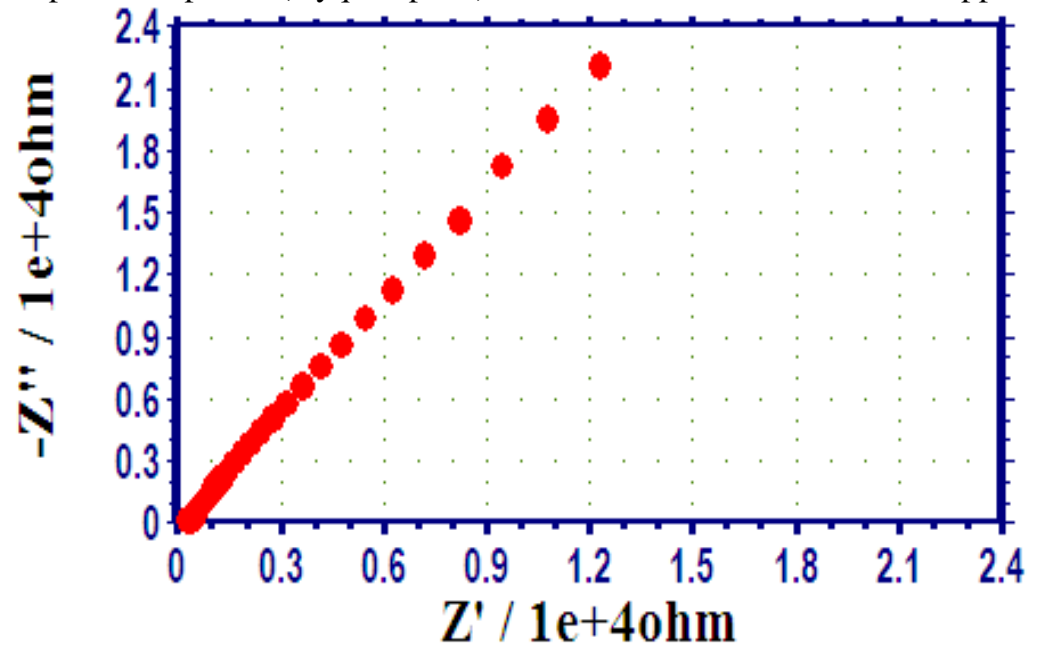

Fig.-7:AC impedance spectra (Nyquist plots) of SS316L immersed in AS +300ppm D-Glucose
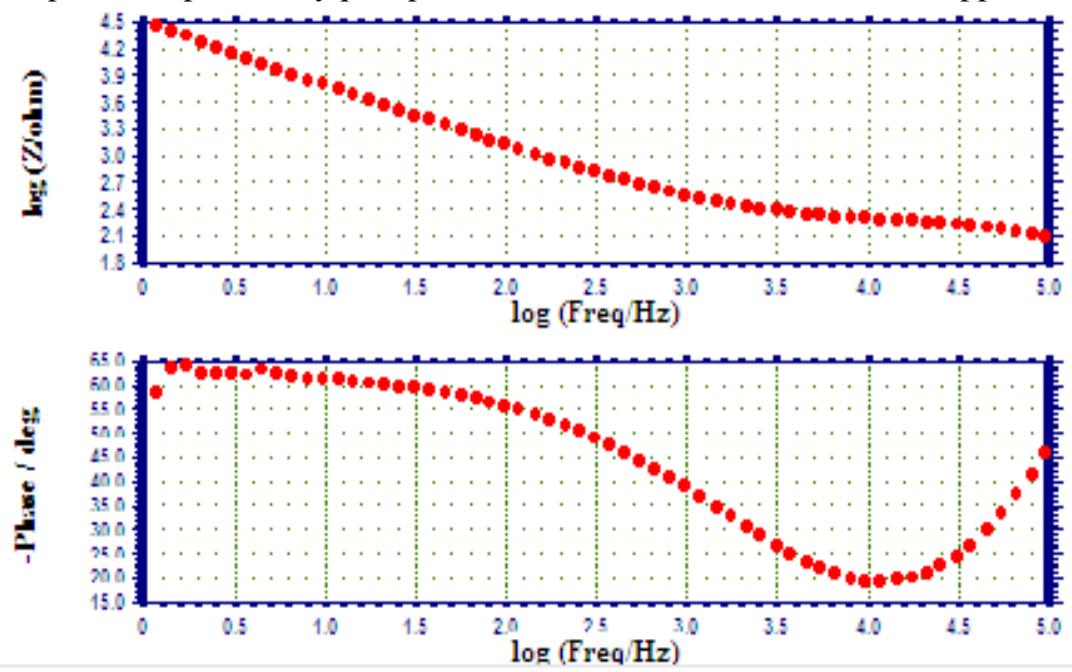

Fig.-8:AC impedance spectra(Bode plots) of SS316L immersed in AS 
RASĀYAN J. Chem.

Vol. 11 | No. 1 |103-110 | January - March | 2018
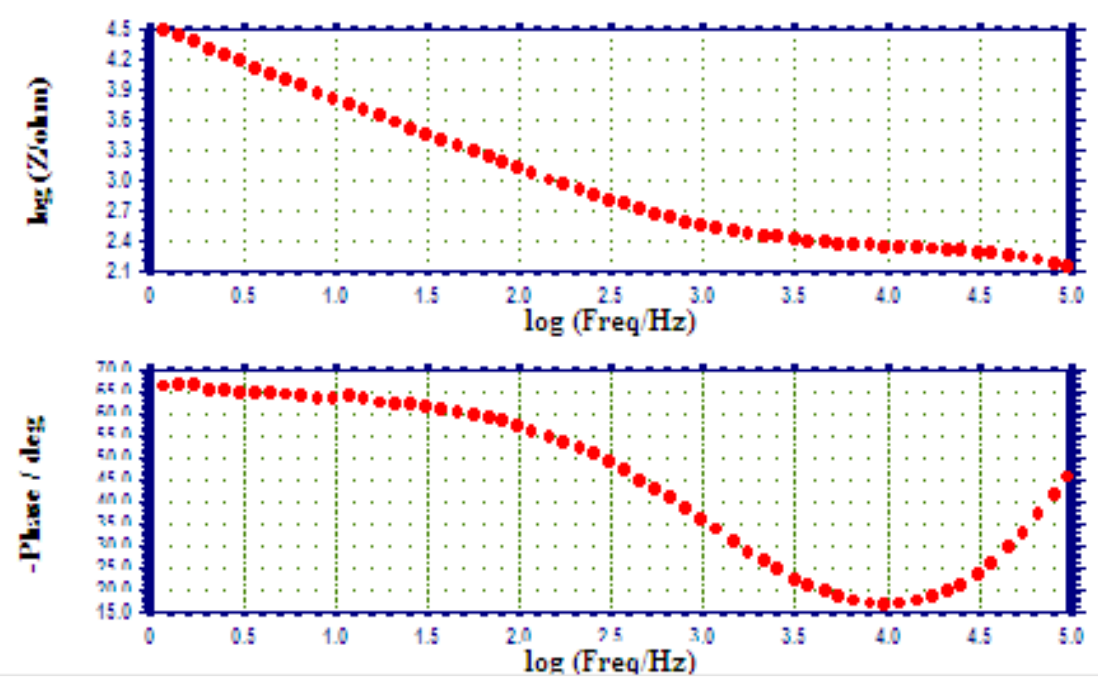

Fig.- 9:AC impedance spectra(Bode plots) of SS316L immersed in AS+150ppm D-Glucose
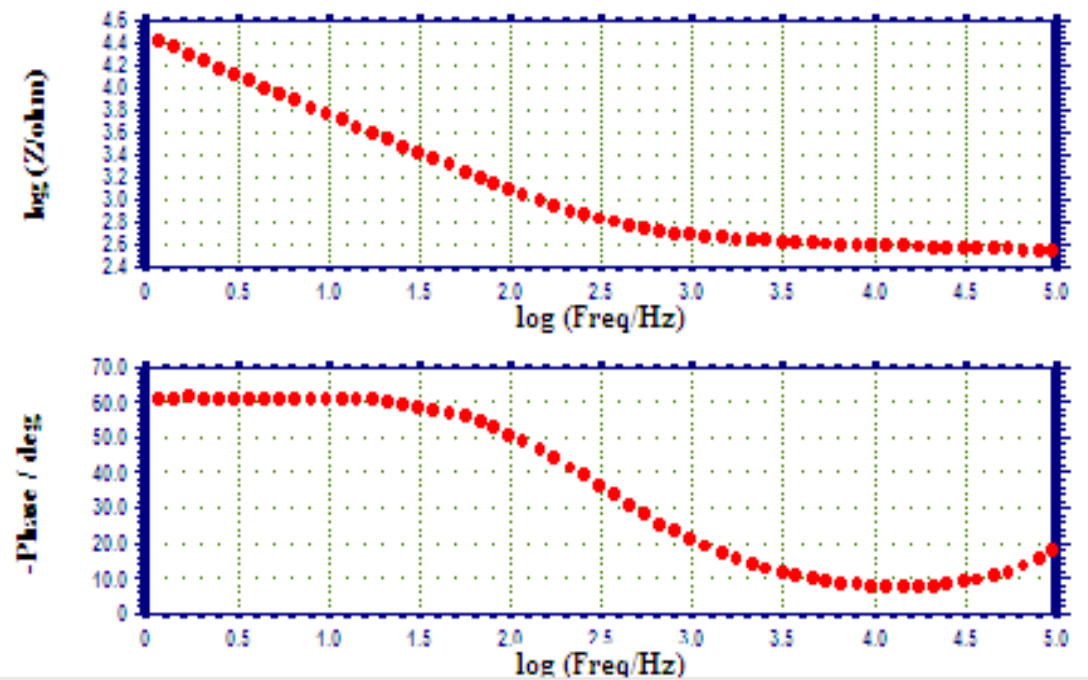

Fig.-10:AC impedance spectra(Bode plots) of SS316L immersed in AS+150ppm D-Glucose

\section{CONCLUSION}

Corrosion resistance of fixed orthodontic wires made up of SS316L immersed in artificial saliva was evaluated with the help of polarization study and AC impedance spectra. The influence of various concentrations of D-Glucose on the corrosion resistance of the above orthodontic wires has been investigated. It is observed that for the SS316L system, the corrosion resistance increases with the increase of D-Glucose concentration. The orthodontic wire immersed in artificial saliva D-Glucose $(150,300 \mathrm{ppm})$, the shifts depends on the concentration D-Glucose in the medium. The present study concludes that the people having implanted with orthodontic wires made of SS316L need not bother about corrosion and hesitate to take D-Glucose orally.

\section{REFERENCES}

1. Gurapa, Materials Characterization, 49, 73 (2002).

2. S. Gustavo, B. Duffo, Silvia Farina, Materials Chemistry and Physics, 115, 235 (2009).

3. B. Zhang, Y.F. Zheng, and Y. Liu, Dental Materials, 25, 672 (2009).

4. B. Siva Kumar, Satendrakumar and T. S. N. Sankara Narayanan, Wear, 270, 317(2011).

5. C. O. A. Olsson, and D. Landolt, Electrochemical Acta, 48(9), 1093 (2003). 
RASĀYAN J. Chem.

Vol. 11 | No. 1 |103-110 | January - March | 2018

6. D. Landolt, Corrosion and Surface Chemistry of Metals, CRC Press, Lausanne,( 2007).

7. D. F. Williams, Biocompatibility of Clinical Implant Materials, CRC Press, Boca Raton, (1982).

8. M. J. Yaszemski,Biomaterials in Orthopedics, Marcel Dekkel Ltd, NY, (2003).

9. C. Ergon, R.M. Doremos, and W. A. Canford, Acta Materialia, 52, 4767 (2004)

10. A. Shahryari, J.A Omanovic, Szpunav, Materials Science and Engineering, 28, 94(2008).

11. S. Viennot, M. Lissac, G. Malquarti, F. Dalard, and B. Grosgogeat, Acta Biomaterialia, 2, 321 (2006).

12. M. A. Christoper, and Brettloana Muresan, Key Eng Mater, 230, 459 (2002).

13. J. M. Meyer, Corro. Sci.,17, 971(1997).

14. S. Rajendran, J. Paulraj, P. Rengan, J. Jeyasundari and M. Manivannan, J. Dentistry and Oral Hygine, 1(1), 001 (2009).

15. S. Rajendran ,P. Chitradevi, S. JohnMary, A. Krishnaveni, S. Kanchana, J. Lydia Christy, R. Nagalakshmi and B.Narayanasamy, Zastita Materijila, 51,149 (2010).

16. M. Pandiarajan and S. Rajendran, Eur. Chem. Bull., 1(7), 238 (2012).

17. A. Leema Rose, Felicia Rajammal Selva Rani, A.Peter Pascal Regis, R. Susai Rajendran, S. Kanchanaand A. Krishnaveni, Zastita Materijila, 50, 187 (2009).

18. E. Kalman, B. Varhegyi, I. Felhosi F.H. Karmanand A. Shaban, J. Electrochem. Soc., 141, 3357 (1994).

19. M. A. Ammer, E. Khamis and M.Al-Motlaq, Corrosion Sci.,46, 2825 (2004).

20. V. Sribharathy and S. Rajendran, J. Electrochem. Sci. Engg., 2, 121 (2012).

21. A. Haraharaputharn, A. Subramanian, A. Antony, P. Manishankar, T. Vasudevan and S.V.Iyer, AntiCorrs. Methods. Mater., 46, 35(1999).

22. C. Mary Anbarasi and S. Rajendran, Chem. Engg. Comm., 99, 1596 (2012).

23. S. Rajendran, B. V. Apparao and N. Palanisamy, Anti-Corros Methods Mater., 49, 205 (2000). I

24. R. Nagalakshmi, S. Rajendran, J. Sathiyabama, M. Pandiarajan. and J.L.Christy, Eur. Chem. Bull, 2(4), 150 (2013).

25. S. SyedAbuthahir, A. Jamal Abdul Nasser and S. Rajendran, Eur. Chem. Bull., 3(1), 40 (2014).

26. A. John Amalraj, J. Wilson Sahayaraj, C. Kumar, S. Rajendran, A. Peterpascal Regis, S. K. Selvaraj, R. Mohan, Eur. Chem. Bull., 2(6), 315 (2013).

27. J. Jeyasundari, Y. Brightson Arul Jacob, S. Rajendran, J. Che. Bio. PhySci., 3(1), 58 (2012).

28. S. Agnesia Kanimozhi, S. Rajendran, Chem. Bio. Phy.Sci., 2(1), 82 (2012).

29. J. Sathiyabama, S. Rajendran, J. Arockiaselvi, J. Jeyasundari, The Open Corrosion Journal, 2, 77 (2009).

30. S. Rajendran, M. Kangamani, M. Sivakalaivani, J. Jeyasundari, B. Narayanasamy, K. Rajam, Zastita Mater, 49, 19 (2008).

[RJC-1747/2017] 